\title{
Penerapan Model Pembelajaran Auditory Intellectually Repetition dengan Permainan Balap Sepeda untuk Meningkatkan Prestasi Belajar Matematika Siswa Kelas XI MIA 5 SMAN 1 Kesamben
}

\author{
Prawoto \\ SMAN 1 Kesamben, Kab. Blitar \\ Email: dimasprawoto073@gmail.com
}

\begin{abstract}
Abstrak: Penelitian ini bertujuan untuk meningkatkan prestasi belajar pada siswa kelas XI MIA 5 SMAN 1 Kesamben kabupaten Blitar pada semester genap tahun pelajaran 2015/2016 dengan pembelajaran dengan model Auditory Intellectually Repetition (AIR) dengan permainan balap sepeda pada Ms. Powerpoint pada pokok bahasan Limit Fungsi. Model pembelajaran $A I R$ dengan siswa menyimak masalah, mengemukakan, menanggapi, serta mempresentasikan jawaban pada tahap auditory. Kegiatan siswa untuk mengkonstruksi, memecahkan masalah dan menerapkan konsep materi yang dipelajari pada tahap intellectually. Siswa mengerjakan latihan soal merupakan

Tersedia Online di

http://journal.unublitar.ac.id/pendidikan/in dex.php/Riset_Konseptual

Sejarah Artikel

Diterima pada : 29-10-2021

Disetujui pada : 29-10-2021

Dipublikasikan pada : 31-10-2021

Kata Kunci:

Auditory Intellectually Repetition, Permainan Balap Sepeda

DOI:

http://doi.org/10.28926/riset_konseptual.v5i4.435 kegiatan pada tahap repetition. Penelitian ini merupakan penelitian tindakan kelas (PTK) pada siswa berjumlah 38 siswa. Prosedur pengumpulan data yang digunakan meliputi tes tertulis dan observasi.Hasil penelitian menunjukkan bahwa prosentase ketuntasan belajar matematika meningkat dari 94,29\% siswa yang tuntas pada siklus I menjadi $97,22 \%$ siswa yang tuntas pada siklus II. Dengan demikian, prestasi siswa pada siklus II mengalami peningkatan sebesar $2,93 \%$.
\end{abstract}

\section{PENDAHULUAN}

Berdasarkan observasi awal yang dilakukan peneliti pada Januari 2016, beberapa siswa kelas XI MIA 5 SMAN 1 Kesamben beranggapan bahwa matematika merupakan pelajaran yang sulit dipahami. Bahkan tidak jarang ditemukan siswa yang mengatakan bahwa matematika itu membosankan dan tidak menarik. Ada pula yang beranggapan bahwa pembelajaran matematika terlalu sulit, sehingga timbul keengganan untuk mempelajarinya. Banyak siswa yang tidak memperhatikan penjelasan guru, sehingga tidak memahami materi yang diajarkan. Hanya beberapa siswa yang mau mencoba mengerjakan dan mempresentasikan tugas yang diberikan guru. Berdasarkan hasil ulangan harian pertama diperoleh informasi bahwa 20 siswa (53\%) tuntas belajar dan 18 siswa (47\%) belum tuntas belajar. KKM yang ditetapkan sekolah adalah 75 , sedangkan rata-rata nilai siswa adalah 74,3 . Hal ini menunjukkan bahwa daya serap siswa terhadap pelajaran perlu ditingkatkan. Penelitian tentang model pembelajaran Auditory Intellectually Repetition pernah dilakukan oleh Nur S (2011) menunjukkan bahwa penggunaan model AIR dapat meningkatkan prestasi belajar siswa kelas VIII SMP Negeri 2 Sidoharjo sebelum penelitian $15,7 \%$ dan meningkat menjadi 66\% setelah penelitian (Nur S. , 2011). Lebih lanjut Saraswati (2014) menunjukkan bahwa penggunaan model AIR dapat meningkatkan prestasi belajar siswa kelas X jurusan pemasaran SMK Batik 1 Surakarta bahwa prestasi belajar sebelum penelitian $15,15 \%$ dan meningkat menjadi $60,6 \%$ setelah penelitian. 
Berdasarkan uraian di atas, peneliti tertarik melakukan penelitian tindakan kelas dengan judul Penerapan Model Pembelajaran Auditory Intellectually Repetition dengan Permainan Balap Sepeda Untuk Meningkatkan Prestasi Belajar Matematika Siswa Kelas XI MIA 5 SMAN 1 Kesamben. Penelitian ini berbeda dengan penelitian yang ada. Perbedaannya terdapat pada latihan mengerjakan soal. Pada penelitian Supriyatun dan Saraswati, siswa mengerjakan soal secara individu, sedangkan pada penelitian ini siswa mengerjakan secara berkelompok melalui permainan balap sepeda. Fokus penelitian ini adalah bagaimanakah deskripsi langkah-langkah pembelajaran model auditory intellectually repetition dengan permainan balap sepeda yang dapat meningkatkan prestasi belajar matematika siswa kelas XI MIA 5 SMAN 1 Kesamben?.

Shoimin (Shoimin, 2014) dan Suherman (dalam (Aulia, 2015) berpendapat mengenai model pembelajaran $A I R$ dapat diambil kesimpulan model pembelajaran $A I R$ adalah model pembelajaran yang dilakukan dengan cara meminta siswa menyimak masalah, mengemukakan, menanggapi, serta mempresentasikan jawaban, setelah itu, siswa mengerjakan latihan soal. Siswa menyimak masalah, mengemukakan, menanggapi, dan mempresentasikan jawaban kelompok merupakan kegiatan pada tahap auditory. Kegiatan siswa untuk menkonstruksi, memecahkan masalah dan menerapkan konsep materi yang dipelajari merupakan kegiatan pada tahap intellectually. Siswa mengerjakan latihan soal yang bertujuan untuk menambah pemahaman siswa terhadap materi yang dipelajari merupakan kegiatan pada tahap repetition.

Beberapa kelebihan dapat disimpulkan bahwa model pembelajaran AIR memiliki banyak kelebihan. Kelebihan tersebut adalah melatih siswa untuk aktif, memecahkan masalah secara kreatif, melatih pendengaran dan keberanian siswa dalam mengungkapkan pendapat, mengingat kembali tentang materi yang telah dipelajari, memberi siswa kesempatan lebih banyak dalam memanfaatkan pengetahuan dan keterampilan secara komprehensif, melatih respon siswa yang berkemampuan rendah terhadap permasalahan yang diberikan dengan cara mereka sendiri, dan memberikan pengalaman siswa untuk menemukan sesuatu dalam menjawab permasalahan.

Sedangkan kekurangan model pembelajaran AIR dapat disimpulkan membuat dan menyiapkan masalah matematika yang bermakna bagi siswa bukanlah pekerjaan mudah, mengemukakan masalah yang langsung dapat dipahami siswa sangat sulit sehingga banyak siswa yang mengalami kesulitan untuk merespon permasalahan yang diberikan, menimbulkan perasaan ragu dalam menjawab, dan membutuhkan waktu yang lama. Sutikno dalam (Sadiman, 2012) yang menyatakan permainan dapat membangun suasana belajar yang dinamis, penuh semangat, dan antusiasme, sehingga menyenangkan bagi siswa. Sehingga membuat permainan adu cepat dalam menjawab latihan soal dengan nama "Permainan Balap Sepeda." adalah permainan adu cepat dalam menjawab latihan soal yang ditayangkan melalui slide power point. Permainan ini dilakukan secara berkelompok. Setiap kelompok akan mendapatkan ikon sepeda yang ditampilkan pada slide area permainan balap sepeda (gambar 2.1). Ikon sepeda akan maju jika jawabannya benar. Kelompok yang sepedanya memasuki garis akhir lebih dulu atau paling dekat dengan garis akhir dinyatakan menjadi pemenang.

Pada penelitian ini, permainan balap sepeda akan dimasukkan pada tahap repetition. Kegiatan pada tahap repetition adalah pengulangan, dengan tujuan memperdalam pemahaman siswa yang dilatih melalui pemberian soal atau kuis. Permainan balap sepeda dirasa cocok sebagai variasi dalam model pembelajaran $A I R$, oleh karena itu peneliti tertarik untuk menerapkan permainan ini. 


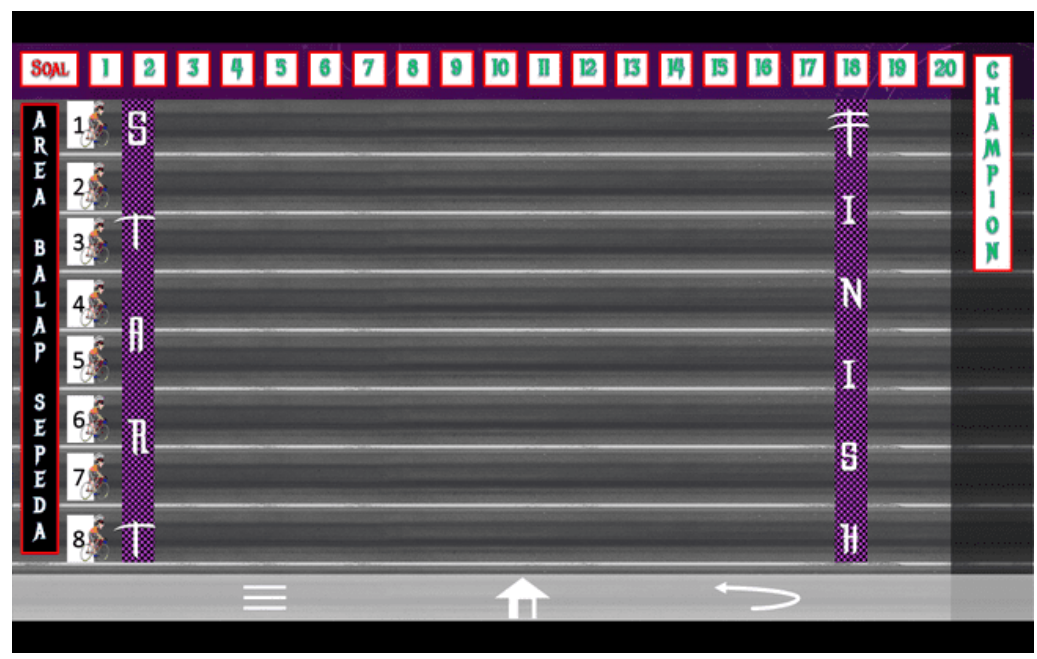

Sumber: Diadopsi Ms Powerpoint Penelitian Gambar 2.1. Slide Area Permainan Balap Sepeda

Aturan permainan menurut Sadiman (Sadiman, 2012) et al. (2012:75) dan Tedjasaputra (Tedjasaputra, 2008) harus diberikan sebelum permainan dimulai, selain itu aturan permainan harus dimengerti oleh setiap pemain dan bersedia mengikuti aturan permainan. Pada aturan permainan balap sepeda dalam penelitian ini seperti pada gambar 2.2.

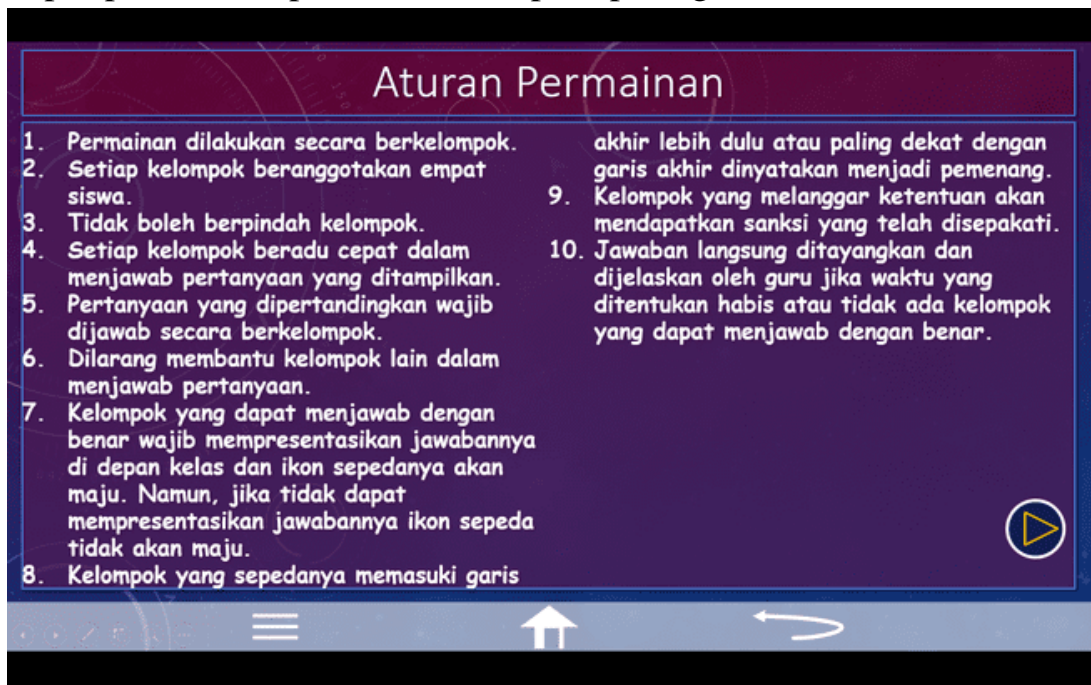

Sumber: Diadopsi Ms Powerpoint Penelitian

\section{Gambar 2.2. Slide Aturan Permainan Balap Sepeda}

Pada slide soal permainan balap sepeda terdapat beberapa fitur, diantaranya: nomor soal, soal, batas waktu pengerjaan soal, ikon untuk menampilkan jawaban, dan ikon untuk kembali ke area balap sepeda. Nomor soal ditampilkan di tengah slide bagian atas. Soal yang diberikan ditampilkan pada bagian tengah slide. Batas waktu mengerjakan soal ditampilkan pada pojok kanan atas. Batas waktu dalam mengerjakan soal bervariasi, dari 60 sampai 180 detik, batas waktu disesuaikan dengan tingkat kesulitan soal. Selain itu diberikan ikon untuk menampilkan jawaban, yang diberi nama "Cek Jawaban" dan diberikan ikon untuk kembali ke area permainan, yang diberi nama "Ke Sirkuit." 


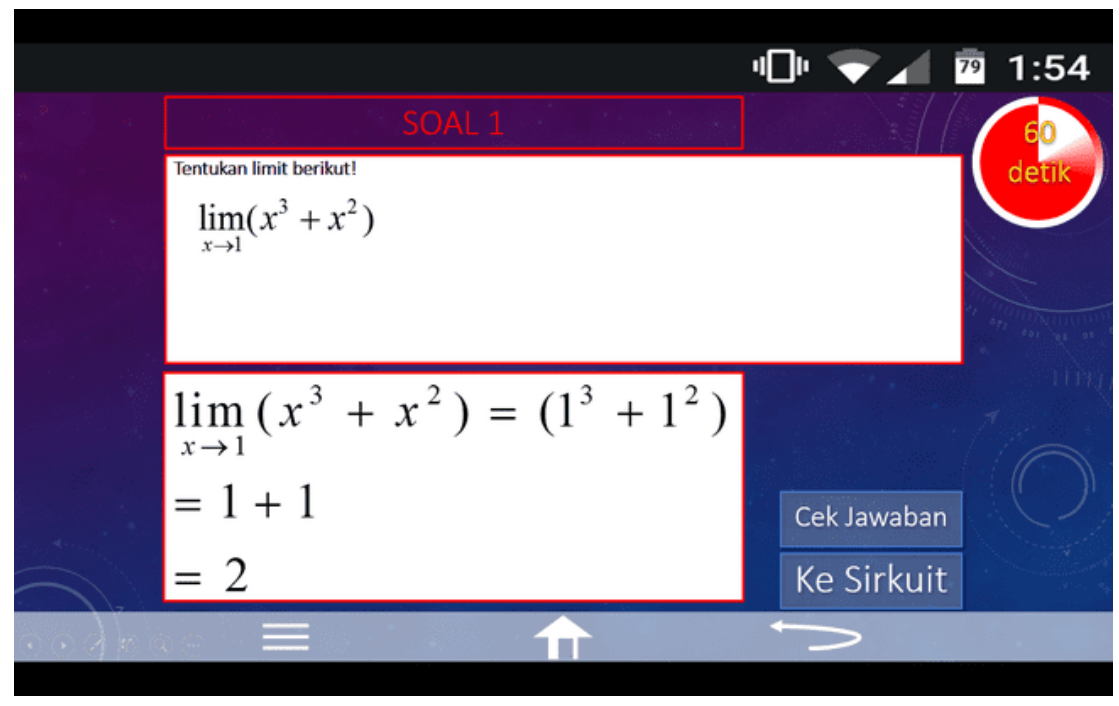

Sumber: Diadopsi Ms Powerpoint Penelitian

\section{Gambar 2.3. Contoh Slide Soal Beserta Pembahasan Permainan Balap Sepeda}

Untuk mengukur prestasi belajar, diperlukan suatu tes. Menurut Arikunto (Arikunto, 2012) Pengukuran prestasi belajar siswa yang digunakan dalam penelitian ini adalah tes subjektif berbentuk uraian. Tes uraian dipilih karena tes uraian menuntut siswa untuk mengorganisir, menyusun, dan memadukan pengetahuan-pengetahuan yang telah dipelajari. Dengan tes uraian, siswa dapat mengemukakan pendapat kemudian menyusunnya dalam bentuk kalimat. Selain itu, penggunaan tes uraian dalam penelitian ini dimaksudkan agar siswa benarbenar mengerjakan tes sesuai kemampuan yang mereka miliki.

Langkah-langkah model pembelajaran AIR dengan permainan balap sepeda yang dilakukan pada penelitian ini adalah sebagai berikut: a) Menyampaikan tujuan pembelajaran yakni menemukan konsep limit fungsi, b) Mengingatkan materi prasyarat dengan menanyakan cara memfaktorkan bentuk aljabar, c) Memberi motivasi melalui pentingnya mempelajari limit fungsi. Limit dipakai dalam salah satu cabang matematika, yaitu analisis matematika untuk mencari turunan dan kekontinuan, d) Menjelaskan langkah-langkah yang harus dilakukan siswa, e) Membagi siswa menjadi beberapa kelompok yang beranggotakan 4-5 siswa berkemampuan heterogen, f) Membagikan LKS tentang konsep limit fungsi aljabar di satu titik, g) Menjelaskan masalah tentang konsep limit fungsi aljabar di satu titik yang ada di LKS, i) Meminta siswa menanyakan masalah yang berkaitan dengan limit, j) Meminta siswa untuk menyebutkan halhal yang terdapat pada limit, k) Meminta siswa bekerja sama dengan anggota kelompok dalam mengerjakan LKS, 1) Membimbing dan mengarahkan kelompok dalam mengerjakan LKS, sehingga dapat menemukan konsep limit fungsi, m) Meminta salah satu kelompok untuk mempresentasikan hasil kerja kelompoknya, n) Menjelaskan dan memantapkan hasil presentasi siswa, o) Menjelaskan aturan permainan, p) Memberikan permainan balap sepeda, q) Menentukan kelompok pemenang, dan r) Membantu siswa menyimpulkan materi yang telah dipelajari.

\section{METODE}

Sumber data penelitian ini adalah siswa kelas XI MIA 5 SMA Negeri 1 Kesamben semester genap tahun pelajaran 2015/2016. Siswa kelas XI berjumlah 38 siswa yang terdiri atas 15 laki-laki dan 23 perempuan. Pemilihan kelas ini berdasarkan pertimbangan bahwa kemampuan siswa kelas XI MIA 5 heterogen. Peneliti melaksanakan pengamatan pada 13-18 April 2016. Tindakan siklus I dilaksanakan Senin, 25 April 2016 dan Rabu, 27 April 2016. 
Tindakan siklus II dilaksanakan Senin, 2 Mei 2016 dan Rabu, 4 Mei 2016. Pemberian tes bertujuan untuk mengetahui prestasi belajar siswa terhadap materi limit fungsi. Tes tulis diberikan pada setiap akhir tindakan. Tes pertama merupakan tes akhir siklus I yang dilaksanakan pada 27 April 2016, sedangkan tes kedua merupakan tes akhir siklus II yang dilaksanakan pada 4 Mei 2016. Lembar observasi digunakan untuk mengamati aktivitas guru (peneliti) dan aktivitas siswa selama proses pembelajaran. Observasi terhadap guru (peneliti) dilakukan oleh guru mata pelajaran matematika. Selain lembar observasi, digunakan catatan lapangan untuk mencatat temuan atau kejadian yang belum tercatat pada lembar observasi.

Keberhasilan belajar siswa dikatakan tuntas jika secara klasikal lebih dari $75 \%$ siswa tuntas belajar. Siswa dikatakan tuntas belajar jika mencapai Kriteria Ketuntasan Minimal yaitu 75. Adapun perhitungan prosentase ketuntasan belajar klasikal adalah sebagai berikut.

$$
P=\frac{n}{N} \times 100 \%
$$

Keterangan: $\mathrm{P}=$ prosentase siswa yang tuntas, $\mathrm{n}=$ banyaknya siswa yang tuntas, $\mathrm{N}=$ banyaknya siswa yang mengikuti tes.

Kriteria keberhasilan proses ditentukan dengan menggunakan lembar observasi yang diisi oleh pengamat. Analisis data hasil observasi menggunakan analisis prosentase. Skor yang diperoleh pada setiap deskriptor dijumlahkan dan hasilnya disebut jumlah skor. Selanjutnya, dihitung prosentase nilai rata-ratanya dengan rumus sebagai berikut.

$$
\text { Persentase nilai rata-rata }(\mathrm{NR})=\frac{\text { skor yang diperoleh }}{\text { skor maksimal }} \times 100 \%
$$

Kriteria penilaian keberhasilan proses ditentukan sebagai berikut $90 \%<\mathrm{NR} \leq 100 \%$ : sangat baik; $75 \%<\mathrm{NR} \leq 90 \%$ : baik; $55 \%<\mathrm{NR} \leq 75 \%$ : cukup baik; $30 \%<\mathrm{NR} \leq 55 \%$ : kurang baik; $0 \%<\mathrm{NR} \leq 30 \%$ : sangat kurang.

Suatu siklus siklus dihentikan jika NR lebih dari 75\% dan prosentase ketuntasan belajar siswa minimal 75\%. Akan tetapi, jika kedua kriteria di atas belum tercapai, maka penelitian akan dilanjutkan pada siklus berikutnya. Arikunto (2008:75) menyatakan banyaknya siklus tergantung dari kepuasan peneliti sendiri, tetapi sebaiknya tidak kurang dari dua siklus (Arikunto, 2012).

\section{HASIL dan PEMBAHASAN}

Pelaksanaan tindakan meliputi beberapa tahap yaitu perencanaan (planning), tindakan (acting), pengamatan (observing), dan refleksi (reflecting). Peneliti dibantu oleh tiga guru matematika untuk mengamati proses pembelajaran. Hasil observasi didasarkan pada hasil diskusi dengan berpedoman pada lembar observasi dan catatan lapangan. Paparan hasil pengamatan diuraikan sebagai berikut: 1) Rata-rata prosentase keberhasilan aktivitas guru siklus I sebesar 88,395 \% yang berarti taraf keberhasilan kegiatan peneliti dalam melaksanakan pembelajaran termasuk dalam kategori sangat baik. Siklus II sebesar 92,265\% juga sangat baik;

Tabel 4.1 Hasil Analisis Lembar Observasi Aktivitas Guru Siklus I dan II

\begin{tabular}{|c|c|c|c|c|}
\hline \multirow{2}{*}{ Siklus } & Pertemuan & $\begin{array}{c}\text { Perolehan } \\
\text { Skor }\end{array}$ & Prosentase & Kategori \\
\hline \multirow{2}{*}{ I } & pertama & 75 & $89,29 \%$ & Baik \\
\cline { 2 - 5 } & kedua & 21 & $87,5 \%$ & Baik \\
\hline \multirow{2}{*}{ II } & pertama & 78 & $92,86 \%$ & Sangat baik \\
\cline { 2 - 5 } & kedua & 22 & $91,67 \%$ & Sangat baik \\
\hline
\end{tabular}


2) Rata-rata prosentase skor keberhasilan aktivitas siswa siklus I sebesar $90,48 \%$ yang berarti taraf keberhasilan kegiatan siswa termasuk dalam kategori sangat baik. Siklus II sebesar 91,67\% juga sangat baik;

Tabel 4.2 Hasil Analisis Lembar Observasi Aktivitas Siswa Siklus I dan II

\begin{tabular}{|c|c|c|c|c|c|c|}
\hline Siklus & Pertemuan & Pengamat & $\begin{array}{c}\text { Perolehan } \\
\text { Skor }\end{array}$ & Prosentase & $\begin{array}{l}\text { Rata- } \\
\text { Rata }\end{array}$ & Kategori \\
\hline \multirow[t]{4}{*}{ I } & \multirow{2}{*}{ pertama } & Kedua & 74 & $88,1 \%$ & \multirow{2}{*}{$88,7 \%$} & \multirow{2}{*}{ Baik } \\
\hline & & Ketiga & 75 & $89,29 \%$ & & \\
\hline & \multirow{2}{*}{ kedua } & Kedua & 22 & $91,67 \%$ & \multirow{2}{*}{$\begin{array}{c}91,67 \\
\%\end{array}$} & \multirow{2}{*}{$\begin{array}{c}\text { Sangat } \\
\text { baik }\end{array}$} \\
\hline & & Ketiga & 22 & $91,67 \%$ & & \\
\hline \multirow[t]{4}{*}{ II } & \multirow[t]{2}{*}{ pertama } & Kedua & 78 & $92,86 \%$ & \multirow{2}{*}{$\begin{array}{c}91,67 \\
\%\end{array}$} & \multirow{2}{*}{$\begin{array}{l}\text { Sangat } \\
\text { baik }\end{array}$} \\
\hline & & Ketiga & 76 & $90,48 \%$ & & \\
\hline & \multirow{2}{*}{$\begin{array}{l}\text { Pertemuan } \\
\text { kedua }\end{array}$} & Kedua & 22 & $91,67 \%$ & \multirow{2}{*}{$\begin{array}{c}91,67 \\
\%\end{array}$} & \multirow{2}{*}{$\begin{array}{c}\text { Sangat } \\
\text { baik }\end{array}$} \\
\hline & & Ketiga & 22 & $91,67 \%$ & & \\
\hline
\end{tabular}

3) Hasil analisis tes akhir siklus I menunjukkan bahwa siswa yang tuntas belajar sebanyak 33 siswa dari 35 siswa yang mengikuti tes. Tiga siswa tidak mengikuti tes karena sakit. Dari data tersebut dapat diketahui prosentase siswa yang tuntas sebesar $94,29 \%$ dan prosentase siswa yang tidak tuntas belajar sebesar 5,71\% dengan nilai rata-rata kelas 92,51. Hasil analisis nilai tes akhir siklus II menunjukkan bahwa siswa yang tuntas belajar sebanyak 35 siswa dari 36 siswa yang mengikuti tes, sehingga prosentase siswa yang tuntas sebesar $97,22 \%$ dan prosentase siswa yang tidak tuntas belajar sebesar 2,78\% dengan nilai rata-rata kelas 97,03. Hasil analisis nilai tes siswa pada siklus II dapat dilihat pada tabel 4.3 berikut ini.

Tabel 4.3 Hasil Analisis Nilai Tes Siswa Siklus I dan II

\begin{tabular}{|c|l|c|c|}
\hline \multirow{2}{*}{ Siklus } & \multicolumn{1}{|c|}{ Keterangan } & Nilai & Prosentase \\
\hline \multirow{2}{*}{ I } & Jumlah siswa yang tuntas & 33 & $94,29 \%$ \\
\cline { 2 - 4 } & Jumlah siswa yang tidak tuntas & 2 & $5,71 \%$ \\
\cline { 2 - 4 } & Rata-rata nilai & 92,51 & \\
\hline \multirow{2}{*}{ II } & Jumlah siswa yang tuntas & 35 & $97,22 \%$ \\
\cline { 2 - 4 } & Jumlah siswa yang tidak tuntas & 1 & $2,78 \%$ \\
\cline { 2 - 4 } & Rata-rata nilai & 97,03 & \\
\hline
\end{tabular}

4) Siswa lebih mudah memahami materi menggunakan LKS; 5) Setiap anggota kelompok hanya memiliki 1 kesempatan untuk mempresentasikan jawaban kelompoknya pada permainan balap sepeda, sehingga tidak ada siswa yang dominan dalam menjawab soal; 6) Dengan permainan balap sepeda, siswa dapat mempresentasikan jawaban kelompoknya, sehingga siswa menjadi lebih percaya diri dalam berbicara di depan kelas; 7) Dengan permainan balap sepeda, siswa dapat berlatih menjawab persoalan dengan cepat dan tepat; 8) Siswa tidak berlatih mengerjakan soal permainan balap sepeda dengan tingkat kesulitan tinggi. Soal nomor 1 sampai 6 merupakan soal dengan tingkat kesulitan rendah, soal nomor 7 sampai 12 merupakan soal dengan tingkat kesulitan sedang, dan soal nomor 13 sampai 20 merupakan soal dengan tingkat kesulitan tinggi. Pada pertemuan pertama siswa hanya memainkan permainan balap sepeda sampai nomor 11 ; 9) Peneliti memberi reward berupa buku dan balpoin untuk juara I permainan balap sepeda dan memberi reward berupa pensil untuk pemenang juara II. Siswa yang memenangkan juara I dan 
II merasa senang, sedangkan siswa yang kalah menerima hasil pertandingan dengan sportif; 10) Peneliti memberi print out soal beserta pembahasan permainan balap sepeda kepada siswa, sehingga banyak soal yang dapat dipelajari siswa; 11) Siswa terlihat percaya diri saat mengerjakan soal tes akhir siklus. Hal ini disebabkan siswa sudah banyak mengerjakan latihan soal yang diujikan melalui permainan balap sepeda. Hasil catatan lapangan pada siklus II dapat dilihat pada tabel 4.4 berikut ini.

Paparan hasil refleksi terhadap pembelajaran diuraikan sebagai berikut: 1) Peneliti memotivasi siswa agar berani tampil di depan kelas untuk menyampaikan hasil diskusi kelompok. Hal ini peneliti lakukan agar siswa lebih berani dan percaya diri untuk mempresentasikan hasil diskusi dan menjelaskan hasil pekerjaan; 2) Peneliti meminta siswa untuk selalu menghargai pendapat siswa lain. Hal ini dimaksudkan agar siswa yang kurang berani dalam menyampaikan pendapat menjadi terbiasa untuk menyampaikan pendapatnya;

Tabel 4.4 Hasil Catatan Lapangan Siklus I dan II

\begin{tabular}{|c|c|c|c|}
\hline $\begin{array}{l}\text { Siklus } \\
\text { ke- }\end{array}$ & $\begin{array}{c}\text { Pertemuan } \\
\text { ke- }\end{array}$ & $\begin{array}{l}\text { Observasi } \\
\text { Aktivitas }\end{array}$ & Keterangan \\
\hline \multirow{4}{*}{ I } & \multirow[t]{2}{*}{1} & Peneliti & $\begin{array}{l}\text { 1. Peneliti tidak memberikan soal dengan tingkat } \\
\text { kesulitan tinggi pada permainan balap sepeda. } \\
\text { 2. Peneliti memberikan hadiah pada juara I dan juara } \\
\text { II permainan balap sepeda. }\end{array}$ \\
\hline & & Siswa & $\begin{array}{l}\text { 1. Saat presentasi, siswa merasa percaya diri. } \\
\text { 2. Siswa tampak bersemangat mengikuti } \\
\text { pembelajaran. }\end{array}$ \\
\hline & \multirow{2}{*}{2} & Peneliti & Peneliti mampu menguasai kelas. \\
\hline & & Siswa & $\begin{array}{l}\text { 1. Siswa berani mempresentasikan hasil pekerjaannya. } \\
\text { 2. Siswa mengerjakan tes dengan percaya diri. }\end{array}$ \\
\hline \multirow{4}{*}{ II } & \multirow[b]{2}{*}{1} & Peneliti & $\begin{array}{l}\text { Peneliti menyajikan soal dengan tingkat kesulitan } \\
\text { rendah, sedang, dan tinggi. }\end{array}$ \\
\hline & & Siswa & $\begin{array}{l}\text { 1. Siswa mulai bisa menerima pembentukan } \\
\text { kelompok secara acak. } \\
\text { 2. Siswa aktif saat diskusi kelompok. } \\
\text { 3. Siswa percaya diri untuk maju mempresentasikan } \\
\text { hasil diskusi kelompoknya. }\end{array}$ \\
\hline & \multirow[b]{2}{*}{2} & Peneliti & Peneliti mampu menguasai kelas. \\
\hline & & Siswa & $\begin{array}{l}\text { Siswa terlihat tidak kesulitan saat mengerjakan soal tes } \\
\text { karena lebih memahami materi yang dipelajari serta } \\
\text { sudah terbiasa mengerjakan soal yang bersifat analisis. }\end{array}$ \\
\hline
\end{tabular}

3) Peneliti perlu memberikan soal dengan tingkat kesulitan tinggi pada permainan balap sepeda. Hal ini perlu dilakukan agar siswa tidak bingung ketika menghadapi soal dengan tingkat kesulitan tinggi; 4) Peneliti memotivasi siswa agar sering berlatih mengerjakan soal. Hal ini peneliti lakukan agar siswa mampu menyelesaikan soal dengan cepat dan tepat; 5) Peneliti memberi reward berupa buku dan ballpoint untuk juara I permainan balap sepeda dan memberi reward berupa pensil untuk pemenang juara ke II. Hal ini dimaksudkan untuk menarik minat belajar dan siswa cepat serta tepat dalam menjawab soal permainan; 6) Peneliti memotivasi siswa untuk rajin belajar dan percaya diri dengan kemampuan yang dimiliki. Hal ini dimaksudkan agar siswa terlatih mandiri ketika menghadapi tes; 7) Peneliti tetap mengadakan siklus kedua walaupun perolehan prestasi belajar siswa sudah memenuhi kriteria klasikal. 
Setelah semua siswa berkumpul dengan kelompoknya, peneliti membagikan LKS pada masing-masing kelompok. Peneliti menjelaskan permasalahan yang diberikan dan menjelaskan pentingnya kegiatan diskusi. Pada kegiatan diskusi, setiap anggota kelompok terlihat antusias mencari jawaban. Setiap anggota kelompok bertukar pikiran untuk memecahkan permasalahan yang diberikan. Siswa yang sudah paham membantu siswa yang belum paham. Kondisi seperti ini sesuai dengan pendapat Gintings bahwa membiasakan siswa dengan berdiskusi akan menumbuhkan sikap ilmiah dan jiwa demokratis kepada siswa (Gintings, 2012).

Setelah diskusi kelompok, peneliti meminta perwakilan tiga kelompok untuk mempresentasikan hasil kerja kelompoknya. Peneliti memberi motivasi kepada siswa agar berani dan percaya diri ketika di depan kelas. Siswa yang maju terlihat percaya diri untuk mempresentasikan hasil diskusi. Hal ini sejalan dengan pendapat Dimyati dan Mudjiono (2013:104) bahwa guru merangsang siswa dengan memberi rasa percaya diri bahwa ia dapat mengatasi segala hambatan dan pasti berhasil (Dimyati dan Mudjiono, 2013).

Pada pertemuan berikutnya peneliti mengadakan tes akhir siklus 1 . Peneliti memotivasi siswa untuk percaya pada diri sendiri. Selain itu, peneliti juga mengingatkan siswa untuk senantiasa jujur dan tidak mencontek dalam mengerjakan tes. Kondisi kelas kondusif saat pelaksanaan tes. Siswa terlihat percaya diri saat mengerjakan soal tes akhir siklus. Siswa mengerjakan tes secara individu.

Pada tindakan siklus II, peneliti memperbaiki kekurangan yang terjadi pada siklus I. Kekurangan pada siklus I adalah siswa tidak berlatih mengerjakan soal dengan tingkat kesulitan tinggi pada permainan balap sepeda. Pada siklus II, peneliti memberi soal dengan tingkat kesulitan yang beragam pada permainan balap sepeda agar siswa mampu mengerjakan soal dengan berbagai tingkat kesulitan. Siswa tampak bersemangat dan lebih tertantang dalam beradu cepat menjawab soal.

Pada kegiatan presentasi, peneliti selalu memberi dorongan dan motivasi kepada siswa untuk berani dan percaya diri tampil di depan kelas. Siswa menjadi tidak malu-malu dan tampak lebih berani dan percaya diri ketika tampil di depan kelas. Siswa yang jarang tampil di depan kelas menjadi terbiasa untuk mempresentasikan jawabannya. Hal ini sesuai dengan pendapat (Dimyati dan Mudjiono, 2013) Dorongan yang berorientasi pada tujuan tersebut merupakan inti motivasi yang dapat meningkatkan kepercayaan diri."

Ketika tes akhir siklus, siswa tampak serius mengerjakan soal tes. Suasana kelas pun kondusif karena tidak ada siswa yang berusaha melihat pekerjaan siswa lain. Siswa terlihat yakin bisa mengerjakan soal tes. Hal ini sesuai dengan pendapat Putri (2014) bahwa siswa yang memiliki rasa percaya diri yang baik cenderung menghindari munculnya perilaku mencontek karena dirinya yakin dengan kemampuan dan usaha yang dilakukan akan memberikan hasil yang diinginkan (Putri, 2014).

\section{KESIMPULAN}

Pada tes akhir siklus I banyaknya siswa yang mencapai KKM sebanyak 33 siswa dari 35 siswa yang mengikuti tes atau sebanyak 94,29\% siswa mencapai ketuntasan. Pada tes akhir siklus II banyaknya siswa yang mencapai KKM sebanyak 35 siswa dari 36 siswa yang mengikuti tes atau sebanyak $97,22 \%$ siswa mencapai ketuntasan. Prestasi siswa pada siklus II mengalami peningkatan sebesar $2,93 \%$, jadi model pembelajaran AIR dengan permainan balap sepeda dapat meningkatkan prestasi belajar siswa.

Untuk memperoleh hasil yang lebih maksimal guru sebaiknya mempersiapkan LKS dan soal permainan yang diperlukan dengan sebaik-baiknya, bertindak aktif untuk selalu memantau, membimbing, memotivasi, dan merespon agar aktivitas diskusi siswa sesuai yang diharapkan dan menciptakan media pembelajaran yang lebih variatif agar proses belajar mengajar menjadi menyenangkan dan siswa lebih tertarik dan termotivasi untuk belajar matematika lebih giat lagi. 


\section{DAFTAR RUJUKAN}

Arifin, Z. (2012). Evaluasi Pembelajaran. Bandung: Remaja Rosdakarya.

Arikunto, S. (2012). Dasar-Dasar Evaluasi Pendidikan. Jakarta: Bumi Aksara.

Arsyad, A. (2009). Media Pembelajaran. Jakarta: Rajawali Pers.

Aulia, N. (2015). Peningkatan Hasil Belajar IPA Melalui Penerapan Model Pembelajaran Auditory Intellectually Repetition (AIR) Dengan Metode Problem Solving Pada Siswa Kelas V A SD Negeri 03 Sulusuban. Lampung: Skripsi Tidak Diterbitkan Universitas Lampung (Online) (http:??digilib.unila.ac.id/10132/ Diakses 18 Maret 2016.

Nur, S. (2011). Peningkatan Minat dan Prestasi belajar Matematika Melalui Model Pembelajaran Kooperatif Tipe Auditory Intellectually Repetition. Surakarta: Skripsi Tidak diterbitkan Universitas Muhammadiyah Surakarta (Online) (http://eprints.ums.ac.id/13835/ diakses 18 Maret 2016.

Putri, P. P. (2014). Hubungan Antara Percaya Diri Dengan Intensi Menyontek. Surakarta: Fakultas Psikologi Universitas Muhammadiyah Surakarta.

Saraswati. (2016). Penerapan Model pembelajaran Auditory Intellectually Repetition Dengan Pendekatan Contextual Teaching and learning (CTL) Dalam meningkatkan Kemampuan Komunikasi dan Prestasi Belajar Matematika Siswa. Surakarta: Skripsi Tidak Diterbitkan Universitas Muhammadiyah Surakarta (Online), http://eprints.ums.ac.id/28706/diakses 18 Maret 2016.

Shoimin, A. (2014). Model Pembelajaran Inovatif Dalam Kurikulum 2013. Yogyakarta: Ar-Ruzz Media.

Soedyarto, Nugroho dan Maryanto. (2008). Matematika Untuk SMA dan MA Kelas XI Program IPA Jilid 2. Jakarta: Pusat Perbukuan Departemen Pendidikan Nasional.

Sugihartono. (2007). Psikologi Pendidikan. Yogyakarta: UNY Press.

Susanto, A. (2013). Teori Belajar dan Pembelajaran Edisi Pertama . Jakarta: Kencana Prenada Media Group.

Susilo, Herawati, dkk. (2012). Penelitian Tindakan kelas sebagai Sarana Pengembangan Keprofesionalan Guru dan Calon Guru. Malang: Bayumedia.

Tedjasaputra, M. (2008). Bermain, Mainan dan Permainan. Jakarta: PT Grasindo.

Usman, M. U. (2008). Menjadi Guru Profesional. Bandung: PT Remaja Rosdakarya.

Yoni. (2010). Menyusun Penelitian Tindakan Kelas. Yogyakarta: Familia Pustaka Keluarga. 